Jurnal Onoma: Pendidikan, Bahasa dan Sastra

ISSN 2443-3667

PBSI FKIP Universitas Cokroaminoto Palopo

Volume 5 Nomor 2

\title{
Peningkatan Kemampuan Menulis Teks Eksplanasi dengan Menggunakan Pendekatan CTL (Contextual Teaching and Learning) Siswa Kelas VIII.B MTs 1 Mare
}

\author{
Rosdiana \\ Universitas Muhammadiyah Makassar \\ rosdiana@unismuh.ac.id
}

\begin{abstract}
Abstrak
Penelitian ini bertujuan untuk mendeskripsikan peningkatan keterampilan menulis teks eksplanasi dengan menggunakan pendekatan CTL (contextual teaching and learning) pada siswa Kelas VIII.B MTs Negeri 1 Mare. Melalui pendekatan CTL (contextual teaching and learning), peningkatan keterampilan menulis teks eksplanasi dapat dilihat secara proses maupun secara produk.Penelitian ini merupakan Penelitian Tindakan Kelas (PTK). Subjek penelitian ini adalah siswa kelas VIII.B MTs Negeri 1 Mare yang berjumlah 20 siswa. Objek penelitian ini adalah keterampilan menulis teks eksplanasi. Penelitian ini dilakukan dengan tahap perencanaan, tindakan, pengamatan, dan refleksi. Data diperoleh dari observasi, wawancara, catatan lapangan, dan dokumentasi. Teknik analisis data dilakukan secara kualitatif dan kuantitatif. Keterampilan menulis teks eksplanasi siswa dilihat dari batas pencapaian Kriteria Ketuntasan Minimum (KKM), yaitu 75 dan menjadi bahan pertimbangan pelaksanaan siklus selanjutnya. Hasil penelitian ini menunjukkan bahwa penerapan pendekatan CTL (contextual teaching and learning) dapat meningkatkan keterampilan menulis teks eskplanasi pada siswa kelas VIII.B MTs Negeri 1 Mare, baik secara proses maupun secara produk. Peningkatan proses ditunjukkan dari sikap siswa, aktivitas siswa, dan suasana pembelajaran, yaitu siswa berpartisipasi aktif dalam pembelajaran menulis teks eksplanasi, siswa berani mengungkapkan pendapat saat berdiskusi, siswa dapat bekerja sama dengan baik dalam kelompok serta siswa dapat mengikuti dan memahami langkah-langkah pendekatan CTL (contextual teaching and learning) dengan baik. Peningkatan produk dapat dilihat dari hasil karya siswa. Pada siklus I, nilai rata-rata siswa 70,6 dengan keterangan siswa tuntas sebanyak 5 siswa atau 20\% siswa. Selanjutnya, pada siklus II rata-rata nilai siswa meningkat menjadi 84,35 dengan keterangan siswa tuntas sebanyak 17 siswa atau $85 \%$ siswa.
\end{abstract}

Kata kunci: menulis, teks eksplanasi, pendekatan CTL (contextual teaching and learning).

\section{Pendahuluan}

Keterampilan menulis merupakan salah satu komponen keterampilan berbahasa yang penting dalam kehidupan pendidikan maupun kehidupan bermasyarakat. Kaitannya dengan pembelajaran di sekolah, keterampilan menulis harus dikuasai oleh siswa. Tujuan yang diharapkan dalam pembelajaran menulis di sekolah agar siswa mampu memahami dan dapat mengemukakan ide, gagasan, pendapat, atau perasaan mereka ke dalam bentuk tulisan. Salah satu kompetensi dasar yang harus dicapai oleh siswa kelas VIII pada silabus Mata Pelajaran Bahasa Indonesia Kurikulum 2013 adalah kegiatan memproduksi teks eksplanasi. Kegiatan memproduksi merupakan bagian dari keterampilan menulis atau menghasilkan tulisan yang menuntut siswa untuk lebih kreatif, inovatif, dan ekspresif dalam mengungkapkan ide atau gagasan.

Halaman | 416 
Teks Eksplanasi pada hakikatnya merupakan teks yang menjelaskan proses. Proses tersebut dapat terjadi secara alamiah, baik yang berkaitan dengan fenomena (gejala) alam maupun fenomena sosial budaya. Pada umunya, teks eksplanasi dibentuk dengan struktur (susunan), yaitu pernyataan umum, penjelasan, dan penutup atau simpulan ( Wahono, dkk. 2013: 107). Selain itu, siswa diharapkan mampu menyusun kerangka teks eksplanasi dan mengembangkan teks eksplanasi ke dalam bentuk tulisan yang utuh dan padu sesuai dengan struktur teks eksplanasi.

Namun, keterampilan menulis teks eksplanasi belum sepenuhnya terlaksana dengan baik, seperti yang terjadi pada siswa Kelas VIII.B MTs Negeri 1 Mare. Berdasarkan hasil observasi kegiatan belajar mengajar terdapat beberapa permasalahan yang teridentifikasi, diantaranya siswa bingung langkah awal apa yang harus dilakukan dalam menulis teks eksplanasi, selain untuk materi atau konsep penulisan teks eksplanasi, peserta didik juga belum dapat membedakan antara teks hasil observasi, tanggapan deskriptif, ekposisi ataupun eksplanasi. Terlebih lagi hal-hal yang terkait dengan struktur yang ada di dalam teks eksplanasi. Peserta didik kesulitan untuk menentukan dan membedakan antara pernyataan umum, deretan penjelas, maupun interpretasi. Dalam menulis teks eksplanasi peserta didik cenderung tidak memiliki minat dan merasa jenuh dengan kegiatan tersebut. Selain itu, guru belum mengoptimalkan strategi pembelajaran yang bervariasi dalam pembelajaran menulis teks eksplanasi sehingga siswa merasa bosan mengikuti pembelajaran.

Berdasarkan permasalahan yang timbul, diperlukan strategi, model ataupun pendekatan yang tepat untuk meningkatkan keterampilan menulis teks eksplanasi pada siswa Kelas VIII.B MTs Negeri 1 Mare. Pendekatan yang diterapkan dalam pembelajaran menulis teks eksplanasi, yaitu pendekatan CTL (contextual teaching and learning). Pendekatan CTL (contextual teaching and learning) dapat membantu siswa untuk memberikan tanggapan secara bebas mengenai karya yang diulas dan melatih siswa untuk menghargai pendapat orang lain. Pendekatan CTL (contextual teaching and learning) juga dapat membantu siswa untuk mengembangkan ide menjadi sebuah tulisan teks eksplanasi.

\section{Metode Penelitian}

\section{Jenis Penelitian dan Desain Penelitian}

Penelitian ini menggunakan desain penelitian tindakan kelas. Penelitian tindakan kelas merupakan suatu bentuk penelitian yang bersifat reflektif dan kolaboratif dengan melakukan tindakan-tindakan tertentu agar dapat memperbaiki dan meningkatkan kualitas pembelajaran dan hasil belajar siswa. Model yang digunakan dalam penelitian ini adalah model Kemmis dan Taggart. Model Kemmis dan Taggart terdiri atas empat tahap, yaitu perencanaan, tindakan, pemantauan, dan refleksi (Arikunto 2015). 
PBSI FKIP Universitas Cokroaminoto Palopo

Volume 5 Nomor 2

\section{Defenisi Operasional Variabel}

Kemampuan menulis adalah suatu kemampuan mengahasilkan suatu karya dalam bentuk tulisan yang berhubungan dengan apa yang dialami dan dirasakan oleh penulis. Dengan tulisan tersebut penulis meluapkan segala apa yang dirasakan, baik perasaan emosi, sedih, seng dan sebagainya. Teks Eksplanasi merupakan teks yang membahas tentang suatu kejadian atau fenomena alam serta penyebab kejadian terebut yang terjadi di lingkungan masyarakat. Pendekatan CTL (contextual taching and learning) merupakan suatu pendekatan yang mengaitkan pembelajaran antara suatu kejadian atau peristiwa yang benar-benar terjadi di lingkungan masyarakat.

\section{Lokasi dan Subjek Penelitian}

Lokasi dari penelitian ini dilakukan di MTs Negeri 1 Mare tepatnya di desa Salubarani Kecamatan Gandangbatu Sillanan Kabupaten Tana Toraja. Arikunto (2015: 188), menjelaskan bahwa subjek penelitian adalah subjek yang dituju untuk diteliti oleh peneliti. Subjek penelitian tindakan kelas ini adalah siswa kelas VIII.B MTs Negeri 1 Mare tahun pelajaran 2018/2019 yang berjumlah 20 siswa dalam 1 kelas.

\section{Prosedur Penelitian}

Prosedur penelitian tindakan kelas terdapat siklus I dan siklus II yang dibagi menjadi empat tahapan yaitu: perencanaan, tindakan, pengamatan atau observasi, dan refleksi. Peneliti melakukan tindakan siklus I dan siklus II, dan akan menerapkan pembelajaran keterampilan menulis teks eksplanasi dengan menggunakan pendekatan CTL (contextual teaching and lerning).

\section{Instrument Penelitian}

Instrument penelitian yang digunakan dalam penelitian ini adalah instrument tes dan nontes. Intrumen tes digunakan dalam mengukur kemampuan peserta didik dalam pembelajaran menulis teks eksplanasi. Sedangkan nontes digunakan untuk mengukur, sikap, social dan proses pembelajaran. Instrument nontes meliputi pedoman observasi, wawancara dan dokumentasi.

\section{Teknik Pengumpulan Data}

Arikunto (2015: 23) menyatakan bahwa instrumen adalah alat atau fasilitas yang digunakan peneliti dalam mengumpulkan data agar pekerjaannya lebih mudah dan hasilnya lebih baik, dalam arti lebih cermat, lengkap, dan sistematis sehingga lebih mudah diolah. Instrumen yang dipakai dalam penelitian ini adalah tes dan nontes.

Teknik pengumpulan data dilakukan dengan cara teknik tes dengan nontes. Teknis tes dalam penelitian ini berbentuk tes praktik menyusun teks eksplanasi secara individu. Teknik tes berfungsi sebagai sarana untuk mengetahui sejauh mana kemampuan peserta didik dalam menerima materi pelajaran berbasis masalah menggunakan pendekatan CTL (contextual teaching 
and learning). Teknik tes dilakukan secara individu, yaitu setiap peserta didik menyusun teks eksplanasi dilakukan pada siklus I dan siklus I.

Sedangkan nontes digunakan untuk mengetahui perubahan prilaku peserta didik dan tanggapan peserta didik terhadap pelaksanaan kegiatan pembelajaran menulis teks eksplanasi menggunakan pendekatan CTL (contextual taching and learning). Teknik nontes dilakukan dengan menggunakan teknik observasi, teknik catatan harian peserta didik, teknik wawancara, dan teknik dokumentasi.

\section{Teknik Analisis Data}

Dalam penelitian ini penulis menggunakan teknik deskriptif kualitatif dan deskriptif kuantitatif.

a. Teknik Deskriptif Kualitatif

Sugiyono (2013: 5), menyatakan bahwa teknik deskriptif kualitatif adalah teknik analisis data yang dilandaskan pada filsafat postpositivisme, digunakan untuk meneliti kondisi objek yang alamiah di mana peneliti adalah sebagai instrumen kunci, pengambilan sampel sumber data dilakukan secara purposive dan snowball, teknik pengumpulan dengan trianggulasi (gabungan), analisis data bersifat induktif/kualitatif, dan hasil kualitataif lebih menekankan makna daripada generalisasi.

Dalam penelitian ini teknik deskriptif kualitatif diambil dari lembar observasi, angket, catatan lapangan, dan dokumentasi foto. Data-data yang diperoleh kemudian dianalisis secara kualitatif dengan serta memadukan secara menyeluruh. Analisis dalam penelitian ini bertujuan untuk mengungkapkan semua perilaku siswa selama pembelajaran menulis teks eksplanasi dengan menggunakan pendekatan CTL (contextual taching and learning) dari kegiatan siklus I dan siklus II.

\section{b. Teknik Deskriptif Kuantitatif}

Sugiyono (2013: 14), mengungkapkan bahwa teknik deskriptif kuantitatif adalah teknik analisis data yang berlandaskan pada filsafat positivisme, digunakan untuk meneliti pada populasi atau sampel tertentu, teknik pengambilan sampel pada umumnya dilakukan secara random, pengumpulan data menggunakan instrumen penelitian, analisis data bersifat kuantitatif/statistik dengan tujuan untuk menguji hipotesis yang telah ditetapkan.

Data kuantitatif yang dikumpulkan berupa skor keterampilan menulis teks eksplanasi sebelum menggunakan pendekatan CTL (contextual taching and learning) dan setelah menggunakan pendekatan CTL (contextual taching and learning). Teknik analisis data kuantitatif dalam penelitian ini dengan menggunakan perhitungan mean (nilai rata-rata hitung). Rumus nilai rata-rata hitung dapat ditulis sebagai berikut: 
PBSI FKIP Universitas Cokroaminoto Palopo

Volume 5 Nomor 2

$$
\begin{aligned}
& X=\frac{\Sigma \mathrm{X}}{N} x 100 \\
& \mathrm{~N} \Sigma \mathrm{X} \text { X Keterangan: } \mathrm{X}=\text { Nilai rata-rata } \\
& \Sigma \mathrm{X} \quad=\text { Nilai yang diperoleh } \\
& \mathrm{N} \quad=\text { Jumlah seluruh siswa }
\end{aligned}
$$

Dari nilai yang diperoleh, siswa dikatakan mampu apabila nilai yang diperoleh dapat mencapai kriteria ketuntasan minimal dengan mengacu pada kriteria ketuntasan minimal yang telah ditentukan.

\section{Indikator Keberhasilan}

Keberhasilan tindakan dalam penelitian ini ditentukan berdasarkan keberhasilan proses dan produk. Kriteria keberhasilan proses, yaitu apabila dalam pelaksanaan tindakan siswa berpartisipasi aktif mengikuti pembelajaran menulis teks eksplanasi, siswa berani mengungkapkan pendapat saat berdiskusi, siswa dapat bekerja sama dengan baik dalam kelompok serta siswa dapat mengikuti dan memahami langkah-langkah pendekatan CTL (contextual teaching and learning) dengan baik.

Keberhasilan produk dapat dilihat berdasarkan pada peningkatan jumlah skor rata-rata yang diperoleh pada setiap siklus. Keberhasilan produk dapat dikatakan berhasil apabila $85 \%$ dari jumlah siswa yang mengikuti pembelajaran menulis teks eksplanasi telah mendapatkan nilai sesuai dengan KKM mata pelajaran bahasa Indonesia, yaitu lebih dari atau sama dengan 75.

\section{Hasil Penelitian \& Pembahasan Keberhasilan Proses}

Keberhasilan proses dapat dilihat dari pengamatan proses yang dilakukan selama pembelajaran menulis teks eksplanasi berlangsung. Penelitian ini dapat dikatakan berhasil apabila siswa memenuhi aspek-aspek pengamatan, yaitu siswa berpartisipasi aktif selama pembelajaran menulis teks eksplanasi, siswa berani mengungkapkan pendapat saat berdiskusi, siswa dapat bekerja sama dengan baik dalam kelompok serta siswa dapat mengikuti dan memahami langkah-langkah pendekatan CTL (contextual teaching and learning) dengan baik.

Pengamatan proses pada setiap pertemuan mengalami peningkatan. Aspek pertama, yaitu keaktifan siswa selama pembelajaran yang diindikatori siswa dapat berpartisipasi aktif dalam pembelajaran menulis teks eksplanasi. Pada tahap siklus I, siswa cenderung pasif dalam kegiatan bertanya jawab. Akan tetapi, setelah diberi tindakan dengan menggunakan pendekatan CTL (contextual teaching and learning), keaktifan belajar siswa semakin meningkat. Siswa bertanya terkait materi yang disampaikan oleh guru, terutama pada bagian struktur dan kebahasaan teks eksplanasi. Siswa merespon pertanyaan dari guru dan menaggapi pertanyaan saat kegiatan diskusi kelompok. Pada tahap merevisi, siswa juga lebih aktif saat bertanya karena dengan kegiatan 
merevisi, siswa menjadi lebih mengerti terkait pemilihan kata, penggunaan kalimat, dan penggunaan EYD yang baik dan benar.

Aspek kedua, yaitu keberanian siswa dalam mengungkapkan pendapat saat berdiskusi. Pada tahap siklus I, siswa masih kurang berani dan kurang percaya diri untuk mengungkapkan pendapat, siswa masih terlihat malu-malu saat merespon atau menjawab pertanyaan dari guru. Hal ini dikarenakan peserta didik belum terlalu paham dengan pendekatan CTL (contextual teaching and learning) yang dipakai oleh peneliti. Kemudian, siklus II dengan menggunakan pendekatan CTL (contextual teaching and learning), siswa menjadi lebih berani untuk mengungkapkan pendapat, siswa juga terlihat lebih memahami materi yang disampaikan oleh guru sehingga saat siswa merespon pertanyaan dari teman maupun guru, siswa dapat menjawab pertanyaan tersebut dengan rasa percaya diri.

Aspek ketiga, yaitu siswa bekerja sama dengan baik dalam kelompok. Pada tahap siklus I, siswa masih banyak yang melamun, ramai sendiri, ngobrol dengan teman sebangkunya sehingga suasana kelas menjadi kurang kondusif walaupun sudah diberi tindakan menggunakan pendekatan CTL (contextual teaching and learning) oleh peneliti. Kemudian pada tahap siklus II, siswa terlihat lebih bersungguh-sunguh saat mengerjakan tugas bersama teman sekelompok sehingga suasana kelas menjadi lebih kondusif, efektif, dan tidak membosankan.

Aspek keempat, yaitu penerimaan siswa terhadap pendekatan CTL (contextual teaching and learning) dalam pembelajaran menulis teks eksplanasi yang diindikatori dengan siswa dapat mengikuti dan memahami langkahlangkah pendekatan CTL (contextual teaching and learning) dengan baik. Pada tahap siklus I, guru belum optimal dalam melakukan pendekatan yang bervariasi dalam pembelajaran menulis teks eksplanasi sehingga siswa terlihat tidak antusias mengikuti pembelajaran menulis teks eksplanasi dan siswa tidak bersemangat ketika diberi tugas menulis, suasana kelas juga kurang kondusif dan pembelajaran terkesan membosankan.

Setelah menggunakan pendekatan CTL (contextual teaching and learning), siswa merasa senang saat pembelajaran diadakan secara berkelompok. Siswa lebih terbantu dan dapat saling memotivasi sehingga siswa lebih bersemangat ketika melihat teman sekelompoknya bersungguh-sungguh saat mengerjakan tugas. Suasana pembelajaran menjadi lebih efektif dan menyenangkan.

\section{Keberhasilan Produk}

Keberhasilan produk dapat dilihat dari pengamatan hasil, yaitu berupa hasil penilaian menulis teks eksplanasi. Siswa dapat dikatakan berhasil dalam pembelajaran ini, apabila telah mencapai nilai sesuai dengan KKM mata pelajaran bahasa Indonesia, yaitu $85 \%$ dari jumlah siswa yang mengikuti 
pembelajaran menulis teks eksplanasi telah mendapat skor lebih dari atau sama dengan 75. Pada tahap siklus I, dari 20 jumlah siswa yang hadir mengikuti tes menulis teks eksplanasi hanya 5 siswa atau $25 \%$ yang tuntas dan sebanyak 15 siswa atau $75 \%$ belum tuntas. Nilai terendah siswa pada tahap siklus I adalah 53 dan nilai tertingginya adalah 90.

Kemudian, pada tindakan siklus II mengalami banyak peningkatan keterampilan menulis teks eksplanasi. Dari 20 siswa yang hadir mengikuti tes menulis teks eksplanasi siklus II, sebanyak 17 siswa atau 85\% siswa memenuhi kriteria ketuntasan penilaian dan 3 siswa atau 15\% siswa belum memenuhi kriteria ketuntasan penilaian. Niai terendah siswa pada siklus II adalah 63 dan nilai tertingginya adalah 95. Adapun peningkatan nilai hasil menulis teks eksplanasi siswa dari siklus I ke siklus II mengalamimpeningkatan sebanyak $60 \%$. Berikut ini perbandingan nilai keterampilan menulis teks eksplanasi pada tahap siklus I dan siklus II.

Tabel Perbandingan Skor Keterampilan Menulis Teks Eksplanasi

\begin{tabular}{cccccc}
\hline Nomor & Nama & Nilai & Katerangan & Nilai & Keterangan \\
& Siklus I & & & Siklus II & \\
\hline 1 & ANDIKA & 73 & Tidak Tuntas & 88 & Tuntas \\
2 & ANISAH & 53 & Tidak tuntas & 73 & Tidak tuntas \\
3 & FADIL & 63 & Tidak tuntas & 83 & Tuntas \\
4 & FAHRIL ILHAM & 55 & Tidak tuntas & 63 & Tidak tuntas \\
5 & FATUR BANGA PADANG & 73 & Tidak tuntas & 88 & Tuntas \\
6 & HASRUL & 55 & Tidak tuntas & 88 & Tuntas \\
7 & MUHAMMAD ARIFKI & 78 & Tidak Tuntas & 85 & Tuntas \\
8 & MUHAMMAD FADLY & 68 & Tidak Tuntas & 83 & Tuntas \\
9 & RAFLY & 70 & Tidak Tuntas & 90 & Tuntas \\
10 & YUSRIVAL MUSRAN & 73 & Tidak Tuntas & 85 & Tuntas \\
11 & MUH. ADAM RAMADHAN P & 83 & Tuntas & 88 & Tuntas \\
12 & CANTIKA RANDALINGGI & 68 & Tidak Tuntas & 88 & Tuntas \\
13 & DWI AYU KARTIKA & 90 & Tuntas & 95 & Tuntas \\
14 & ELSA & 85 & Tuntas & 88 & Tuntas \\
15 & MAYANG SARI & 73 & Tidak Tuntas & 83 & Tuntas \\
16 & NUR FAJRIANI & 70 & Tidak Tuntas & 85 & Tuntas \\
17 & MUTMA INNA & 73 & Tidak Tuntas & 88 & Tuntas \\
18 & NUR ARISKA AMALIA & 83 & Tuntas & 90 & Tuntas \\
19 & NURUL AZIZAH & 53 & Tidak Tuntas & 73 & Tidak Tuntas \\
20 & MELISA A & 73 & Tidak Tuntas & 83 & Tuntas \\
\hline
\end{tabular}

Berdasarkan hasil penelitian tindakan kelas yang dilakukan, dapat ditarik simpulan bahwa penggunaan pendekatan CTL (contextual teaching and learning) dalam pembelajaran menulis teks eksplanasi dapat meningkatkan keterampilan menulis teks eksplanasi pada siswa Kelas VIII.B MTs Negeri 1 
Mare. Peningkatan ini terjadi pada peningkatan proses dan peningkatan hasil. Peningkatan proses terlihat pada aktivitas siswa, sikap siswa, dan suasana pembelajaran selama mengikuti pembelajaran menulis teks eksplanasi, yakni dilihat dari keaktifan siswa, keberanian siswa, kerja sama siswa dalam kelompok, dan penerimaan siswa terhadap pendekatan CTL (contextual teaching and learning).

Pada tahap siklus I walaupun telah diberi tindakan pendekatan CTL (contextual teaching and learning), siswa tidak aktif bertanya jawab dalam mengikuti pembelajaran menulis teks eksplanasi, siswa hanya diam mendengarkan guru dan tidak memanfaatkan kesempatan untuk bertanya jawab. Siswa belum berani mengungkapkan pendapat, hanya beberapa siswa yang merespon atau menanagapi pertanyaan dari guru. Guru belum mengoptimalkan pendekatan yang bervariasi dalam pembelajaran menulis teks eksplanasi sehingga suasana kelas kurang kondusif serta minat dan motivasi siswa mengikuti pembelajaran menulis teks eksplanasi masih kurang.

Pada siklus II, siswa semakin aktif bertanya, keberanian siswa dalam mengungkapkan pendapat semakin meningkat, siswa dapat bekerja sama dengan baik dalam kelompok sehingga suasana pembelajaran lebih efektif, menyenangkan, dan tidak membosankan serta siswa mengikuti dan memahami langkah-langkah pendekatan CTL (contextual teaching and learning) sehingga minat dan motivasi siswa mengikuti pembelajaran menulis teks eksplanasi semakin meningkat.

Peningkatan hasil dengan penerapan pendekatan CTL (contextual teaching and learning) dalam keterampilan menulis teks eksplanasi dapat dilihat dari praktik menulis siswa. Pada tahap siklus I, nilai rata-rata siswa 70 dengan jumlah siswa yang tuntas sebanyak 5 siswa atau 25\% siswa. Selanjutnya, pada siklus II rata-rata nilai siswa meningkat menjadi 85 dengan jumlah siswa yang tuntas sebanyak 17 siswa atau 85\% siswa. Hal ini menunjukkan bahwa keterampilan menulis teks eksplanasi siswa mengalami peningkatan yang signifikan. 
Jurnal Onoma: Pendidikan, Bahasa dan Sastra

ISSN 2443-3667

PBSI FKIP Universitas Cokroaminoto Palopo

Volume 5 Nomor 2

\section{Simpulan}

Berdasarkan data yang diperoleh dapat disimpulkan bahwa penelitian ini menunjukkan bahwa penerapan pendekatan CTL (contextual teaching and learning) dapat meningkatkan keterampilan menulis teks eskplanasi pada siswa kelas VIII.B MTs Negeri 1 Mare, baik secara proses maupun secara produk. Peningkatan proses ditunjukkan dari sikap siswa, aktivitas siswa, dan suasana pembelajaran, yaitu siswa berpartisipasi aktif dalam pembelajaran menulis teks eksplanasi, siswa berani mengungkapkan pendapat saat berdiskusi, siswa dapat bekerja sama dengan baik dalam kelompok serta siswa dapat mengikuti dan memahami langkah-langkah pendekatan CTL (contextual teaching and learning) dengan baik. Peningkatan produk dapat dilihat dari hasil karya siswa. Pada siklus I, nilai rata-rata siswa 70,6 dengan keterangan siswa tuntas sebanyak 5 siswa atau 20\% siswa. Selanjutnya, pada siklus II rata-rata nilai siswa meningkat menjadi 84,35 dengan keterangan siswa tuntas sebanyak 17 siswa atau $85 \%$ siswa

\section{Daftar Pustaka}

Arikunto, Suharsimi. 2015. Penelitian Tindakan Kelas. Jakarta: Bumi Aksara.

Sugiyono. 2013. Metode Penelitian Pendidikan Pendekatan Kuantitatif, Kualitatif, dan $R \& D$. Bandung: Alfabeta

Wahono, dkk. 2013. Mahir Berbahasa Indonesia untuk SMP/ MTs. Kelas VIII. Jakarta: Erlangga.

Halaman | 424 